\title{
6. Perspectives on the answers of the ECJ
}

\section{INTRODUCTION: GENERAL SATISFACTION}

The previous chapter focused on the views of national judges on the quality of their interaction with the ECJ. It revealed that judges do not feel that this interaction is a genuine dialogue. This chapter focuses on judges' perspectives on the requested rulings. The national court judges interviewed were generally satisfied with the judgments of the ECJ: almost all considered them to be useful and of a high quality. ${ }^{1}$ At the same time, however, almost all judges could point to some problematic judgments. A similar sentiment was reported by van Gestel and de Poorter based on interviews with judges of the supreme administrative courts in ten EU Member States. ${ }^{2}$

The Irish judges were the most positive and emphasized that they were dissatisfied with only a small minority of ECJ judgments. ${ }^{3}$ The Dutch highest administrative courts and the UK courts were slightly more negative on the whole and highlighted the varying quality of ECJ judgments. ${ }^{4}$ The UK courts have frequently expressed their frustration in this regard in rather explicit terms in their judgments. Part of this frustration is due to a feeling that their tradition is alien to the ECJ and that ECJ judgments are not written for them. ${ }^{5} \mathrm{UK}$ judges expressed concerns about the civil law nature of the EU legal system as well as the brevity of ECJ judgments. ${ }^{6}$ Similar feelings were voiced by Irish judges, but this did not significantly influence their overall appraisal of the judgments of the ECJ. Even the UK judges interviewed pointed to many high-quality and

\footnotetext{
1 Interviews $10,12,15,18,24,27,30,33,34,41,44,45,66,72,77,78,82,87,91$, 105, 108, 113, 133, 136, 139, 144, 152, 166, 181, 187 and 191.

2 Van Gestel and de Poorter 2019, 135. Cf Eliantonio and Favilli 2020.

3 Interviews 113, 171 and 181.

4 Interviews 18, 24 and 89.

5 Interviews 139, 144, 152, 181, 187, 191, 211 and 231; Lord Mackay as quoted by Littlepage 2014, 207. Cf Arden 2010, 16 and 19; Mance 2013a, para 23.

6 Interviews 139, 144, 152, 181, 187, 191, 211 and 231; Arden 2010, 16 and 19; Mance 2013a, para 23; HS2 Action Alliance Ltd, $R$ (on the application of) $v$ The Secretary of State for Transport \& Anor [2014] UKSC 3, para 128 (Lord Sumption).
} 
well-argued ECJ judgments. ${ }^{7}$ One Dutch judge suggested that, on average, 80 per cent of ECJ judgments are satisfactory; while another judge was slightly more negative and put this figure at 70 per cent. ${ }^{8}$ Some tax judges of the Dutch Supreme Court were cautious in voicing criticism, suggesting that ECJ judgments should not be dismissed as the utterings of an 'oracle' and that national court judges should not speak 'sharply and unpleasantly' about ECJ judgments. ${ }^{9}$ One judge noted that, from a legal dogmatic perspective, the ECJ cannot issue a wrong judgment, since ECJ judgments are by definition law. $\mathrm{He} / \mathrm{she}$ added that if a judge were to say that the applicable law was wrong, this would be the same as an astronomer saying that the moon is wrong. That said, he/she admitted that judges sometimes have reservations about ECJ rulings in a personal capacity. ${ }^{10}$

The judges interviewed contextualized the criticisms discussed in the rest of this chapter in three ways. First, they noted that judgments are never unanimously applauded. ${ }^{11}$ One former UK Supreme Court judge observed that it is human nature to complain about problems and emphasized that no court is perfect - even the 'thin-skinned' Supreme Court. ${ }^{12}$ Lady Justice Arden acknowledged that Luxembourg, "like any other court, do[es] not always get it right'. ${ }^{13}$ Dutch judges similarly stated that they themselves are often subject to criticism and reasoned that the ECJ is 'just a court', like any other. ${ }^{14}$

Second, judges pointed to the difficult task of the ECJ, which must take into account 28 different legal systems and 23 official languages. ${ }^{15}$ Given the challenges of accommodating many different legal areas and specializations, they suggested, the ECJ 'is doing a damn good job' ${ }^{16}$ One Dutch Supreme Court judge even expressed 'admiration' for the ECJ, having learned from his/her experience as a judge in the Benelux Court - which covers three neighbouring countries and two languages - how difficult the task of an international court is. ${ }^{17}$ An Irish judge similarly cautioned that 'none of the tasks of the ECJ are 2010, 9 .

Interviews 208 and 231. Many ECJ judgments 'can readily be absorbed'. Arden

8 Interviews 10 and 91.

9 Interview 15.

10 Interview 15.

11 Mance 2015, para 3.

12 Interview 231.

13 Arden 2014, 7.

14 Interviews 10, 15, 30, 34, 44, 59 and 82 .

15 Interviews 15, 18, 32, 34, 41, 43, 44, 87, 91 and 231. Cf van Gestel and de Poorter 2019, 136.

16 Interview 15. Cf Interview 34.

17 Interview 87. 
easy', and that not everything goes smoothly. ${ }^{18}$ Another Irish interviewee remarked that it is 'almost unavoidable' that judgments are sometimes unclear. $\mathrm{He} /$ she noted that this is unsurprising because only one Irish judge, who understands the Irish system, serves on the ECJ. ${ }^{19}$ Hence, 'cultural misunderstandings' can happen and 'difficulties of communication between different legal systems' are unavoidable. ${ }^{20}$

Third, referring courts were also critical of themselves, suggesting that it takes two to tango'. ${ }^{21}$ As will be made clear throughout this chapter, it is often the referring court that is to blame for ill-formulated or overly general questions, which are thus not sufficiently well understood in Luxembourg.

The rest of this chapter focuses on two specific perceived problems with ECJ judgments: the ECJ's inability to answer the questions satisfactorily, if at all (section 2); and the ECJ's failure to appreciate the facts of the case, the national legal framework or the underlying concerns of the referring court (section 3).

\section{NO (CLEAR) ANSWER}

There are various ways in which the ECJ fails to answer (some) questions of the referring national courts. ${ }^{22}$ In some cases, the ECJ does not answer (some of) the questions and declares them inadmissible, or avoids answering them on procedural or substantive grounds (section 2.1). In other cases, the ECJ's answers raise further questions because of deficient reasoning (section 2.2). The ECJ sometimes reformulates the questions of the referring court to such an extent that it fails to address the points raised (section 2.3). Another problem highlighted by the judges interviewed is a lack of consistency in the ECJ case law (section 2.4).

\subsection{Failure to Answer the Question}

On occasion, the ECJ has declared a question inadmissible or has dodged it on - sometimes dubious - procedural or substantive grounds. Former UK Supreme Court President Neuberger noted that ECJ judgments 'occasionally evade the legal question actually raised in order to arrive at a mutually

\footnotetext{
Interview 155.

Interview 113. Cf Interview 155.

20 Interview 181; MMv Minister for Justice [2018] IESC 10 (O’Donnell), paras 315 and 1.

21 Prechal 2014; Timmermans 2015, 114-18.

22 Cf Langer 2015; de Werd 2015a and b; de Witte 2016, 24-25; Eliantonio and Favilli 2020.
} 
acceptable product'. ${ }^{23}$ However, the significance of this problem should not be exaggerated: it seems to be confined largely to cases referred by two of the Dutch highest administrative courts and a few references of the Dutch and UK Supreme Court; and no such recent Irish cases were found. ${ }^{24}$

In Servatius, the ECJ declared inadmissible the seventh question, about services of general economic interest, and limited itself to considering the free movement of capital. This was upsetting to the Council of State, which felt 'downright embarrassed', since the question had been carefully formulated. ${ }^{25}$ In Trijber and Harmsen, the ECJ did not answer the Council of State's question on whether the Services Directive applies to purely internal situations. ${ }^{26}$ The ECJ evaded this key question simply by briefly identifying cross-border elements, even though the Council of State had clearly indicated that both cases concerned purely internal situations and despite the strong warning of AG Szpunar not to dodge the question. The ECJ's initial silence prompted the Council to repeat its question again in Visser Vastgoed. ${ }^{27}$ Once again, however, the ECJ failed to answer a question on the application of the Services Directive in $X$, which concerned the fee levied by the municipality of Amersfoort for the construction of a fibre-optic network. The Supreme Court reasoned carefully why it considered that the Services Directive applied, rather than the Directive on the authorization of electronic communications networks and services; but the ECJ nonetheless answered the question on the basis of the Authorization Directive. ${ }^{28}$ Some interviewees wondered whether this was a wise move and questioned whether the ECJ had properly addressed all the arguments of the Supreme Court. ${ }^{29}$

Something similar happened in Nolan, which was referred by the UK Supreme Court. The ECJ determined that it did not have jurisdiction because the situation did not fall within the scope of Directive 98/95 on collective

\footnotetext{
$23 \quad$ Neuberger 2016, para 37.
}

24 The ECJ did not answer the essential first question of the Central Appeals Tribunal in Martens, about the continued grant of funding for higher education outside the Netherlands, and a case dealing with biometrics, Case C-359/13 Martens EU:C: 2015:118; Joined cases C-446/12 until C-449/12 Willems EU:C:2015:238; Gill-Pedro 2015; Krommendijk 2019b.

${ }_{25}$ Case C-567/07 Servatius EU:C:2009:593.

26 Joined Cases C-340/14 and C-341/14 Trijber and Harmsen EU:C:2015:641; Visser Vastgoed NL:RVS:2016:75, para 20.1.

27 Joined Cases C-360/15 and C-31/16 X and Visser Vastgoed EU:C:2018:44. Cf a repetition of the partly unanswered questions in Case C-189/09 Zuid-Chemie EU:C: 2009:475; Case C-12/15 Universal Music EU:C:2016:449; Universal Music NL:HR: 2015:36, para 4.4; Interview 27.

28 Joined Cases C-360/15 and C-31/16 X and Visser Vastgoed EU:C:2018:44.

29 Interviews 15 and 30. 
redundancies, since it dealt with the termination of an employment relationship between a UK national and a non-Member State..$^{30}$ The Court of Appeal noted in its follow-up judgment that the 'the case took an unexpected turn' before the ECJ, which adopted a 'curious' line and ignored the AG's Opinion. The ECJ raised the issue of the applicability of EU law on its own initiative, following an observation by the European Commission. As a result, the Court of Appeal had to decide an issue that had not arisen in earlier stages of the case ${ }^{31}$ The ECJ also based its decision on an incorrect premise in Vomero that was not even a point of discussion before the UK Supreme Court - possibly because of the observations of AG Szpunar. It assumed that the applicant did not, at the time, have a right of permanent residence. ${ }^{32}$ Partly because of this, the ECJ judgment was surprising to the Supreme Court judges. It left scope for further arguments, since the ECJ avoided answering particular questions on how to calculate the ten-year period to qualify for enhanced protection against expulsion and how to deal with the interruption of continuity of residence. ${ }^{33}$

However, the silence of the ECJ is sometimes due to the order for reference drafted by the referring court, as certain questions or aspects of the case may not have been formulated sufficiently clearly and accurately. The ECJ gave the UK Supreme Court a rap on the knuckles when it failed to include all the necessary information in its reference in Vomero. ${ }^{34}$ Another example is the reference of the Dutch Civil Chamber in Préservatrice Foncière. The ECJ focused exclusively on the liability of the state on the basis of a private law guarantee contract, even though the issue of joint and several liability also required consideration; but the latter had not featured prominently in the order for reference ${ }^{35}$ There is also room to doubt the conclusion of the Dutch Supreme Court in X (municipality Amersfoort), because it paid little attention to the applicability of Article 13 of the Authorization Directive. Supreme Court judges wondered as a result whether they had formulated the questions sufficiently clearly. ${ }^{36}$

\footnotetext{
Case C-583/10 Nolan EU:C:2012:638. Cf Arnull 2017, 350.

The United States of America $v$ Nolan [2014] EWCA Civ 71, para 1.

SSHD v Franco Vomero [2019] UKSC 35, paras 33-34.

Interview 264.

34 Joined Cases C-316/16 and C-424/16 B and Vomero EU:C:2018:256, paras

35 Case C-266/01 Préservatrice Foncière Tiard EU:C:2003:282; Polak 2009,

36 Joined Cases C-360/15 and C-31/16 X and Visser Vastgoed EU:C:2018:44, paras
} $41-42$. 110-11. 55-56; Interview 34. 


\section{$2.2 \quad$ No Clarity}

A frequent complaint both in the literature and among judges is that ECJ judgments often raise more questions than they answer. ${ }^{37}$ This reflects the abundant criticisms of the ECJ's Cartesian 'French-style' reasoning. ${ }^{38}$ Luxembourg insiders share these views. Former ECJ judge Edward pointed to the difficulty in issuing clear decisions due to the nature of collegiate decision making in the ECJ ${ }^{39}$ AG Sharpston pointed to 'gaps in the reasoning' and 'bland opacity in key passages' ${ }^{40}$ Dutch and UK judges have been more critical than their Irish counterparts with respect to the clarity of ECJ judgments. ${ }^{41}$ While Dutch judges noted the generality and the deferential nature of ECJ judgments, UK judges primarily criticized their brevity and limited reasoning.

On the latter point, UK judges freely admit that they sometimes struggle to understand ECJ judgments. ${ }^{42}$ One UK judge pointed to 'muddied answers that keep everyone happy'; while another noted that it is not uncommon for both parties to claim they have won or for the court to be split. ${ }^{43}$ The sparse reasoning of ECJ judgments was considered particularly problematic. Lord Mance noted that 'the Committee style of its judgments restricts the Court's ability to introduce nuance or to express itself always with absolute clarity'; while Lord Reed held that 'it is unrealistic to expect preliminary rulings always to set out a precise rule'. ${ }^{44}$ Lord Carnwath stated that in one case, the Supreme Court argued for hours about the meaning of the ECJ's judgment without reaching agreement; the Supreme Court eventually gave up and asked AG Sharpston for clarification. ${ }^{45}$ Former Supreme Court President Neuberger stated in a public lecture that ECJ judgments are 'not infrequently internally inconsistent ${ }^{4}{ }^{46}$ One example is Newby, in which the UK High Court struggled with the meaning

37 Cf ECJ judgment generated 'a cacophony of questions', Parish 2020.

38 Weiler 2001, 225; Weiler 2013, 235; Jacobs et al 2019, 1216; Pollack 2018; Lasser 2009, 104; BVerfG 2 BvR 859/15, 5, paras 116-18; van Gestel and de Poorter 2019, 9 .

39 Edward 1995, 557.

40 Sharpston 2014, 765.

41 The interviews and legal analysis led to only one case: Case C-470/16 North East Pylon EU:C:2018:185. The ECJ used three different notions about the requirement that judicial environmental procedures are not prohibitively expensive. One Irish judge held that this lack of clarity might have required a second reference. Cf Kokott and Sobotta 2019, 121.

42 Littlepage 2014, 200; Micklitz 2005, 440-41.

43 Interviews 231 and 264.

44 Mance 2013a, para 23; Reed 2014, 6; Arden 2010, 8.

45 Littlepage 2014, 206.

46 Neuberger 2016, para 37. 
of the term 'cutting point' and identified three possible readings of the ECJ judgment. ${ }^{47}$

The UK courts are especially critical of brief ECJ judgments that deviate from the AG's Opinion without a clear explanation. ${ }^{48}$ In Patmalniece, the UK Supreme Court pointed to the profound contrast between the 'lengthy, scholarly and closely-reasoned discussion' of the AG, which concluded that the case dealt with a form of direct discrimination; while the Grand Chamber found that it dealt with a form of indirect discrimination, without any reference to the discussion of these issues by the AG. ${ }^{49}$ Lord Neuberger voiced similar criticisms with respect to another Grand Chamber judgment (Maruko), dismissing it as 'an unreasoned assertion' and contrasting it with the different conclusion in the 'fully reasoned analysis' of the AG. ${ }^{50}$ The UK courts in particular have shown a clear preference for the more discursive AG Opinions. They have even used these Opinions to fill 'lacunae' in ECJ judgments or to understand the 'sparse reasoning' of the ECJ, because of the Opinions' 'fuller discussion of the principles and their practical application' ${ }^{51}$ In the consumer law case Cavendish Square Holding, the UK Supreme Court relied on the AG's Opinion instead of the ECJ judgment. It noted that the AG's analysis was 'in the nature of things more expansive than the court's [and] repays careful study'. Partly on the basis of this study, the Supreme Court arrived - according to the dissenting opinion of Toulson - at a doubtful (not clair) test that watered down the approach of the ECJ. ${ }^{52}$ In other cases, the UK courts have preferred to rely on judgments from other common law countries rather than ECJ judgments, even in fields affected by EU law. ${ }^{53}$

The UK courts are thus particularly critical of ECJ judgments rendered without the help of an AG Opinion. In ClientEarth, both ClientEarth and the

47 Newby Foods Ltd, $R$ (on the application of) v Food Standards Agency [2016] EWHC 408 (Admin), para 66.

48 HS2 Action Alliance Ltd, $R$ (on the application of) $v$ The Secretary of State for Transport \& Anor [2014] UKSC 3, para 188.

49 Patmalniece $v$ The Secretary of Work and Pensions [2011] UKSC 11, para 33 (Lord Hope) and 63 (Lord Walker).

50 Bull \& Anor v Hall \& Anor [2013] UKSC 73, para 81; Case C-267/06 Maruko EU:C:2008:179.

51 HMRC v Aimia Coalition Loyalty UK Ltd [2013] UKSC 15, paras 87 and 130. Cf Tele 2 Nederland and Others $v$ Autoriteit Consument en Markt NL:CBB:2017:213, para 7.2.3; Case C-28/15 KPN EU:C:2016:692; Interviews 108, 139 and 152; Mance 2013a, para 29; Littlepage 2014, 200.

52 Cavendish Square Holding BVv Talal El Makdessi [2015] UKSC 67, paras 107 and 315 .

53 For example, the Supreme Court relied on Australian jurisprudence in a consumer law case concerning the display of cigarettes, Imperial Tobacco Ltd $v$ The Lord Advocate (Scotland) [2012] UKSC 61; Littlepage 2014, 201-03. 
secretary of state claimed victory as a result of the judgment's ambiguity, which resulted from the reformulation of the questions. The UK Supreme Court held that there was no AG Opinion 'to provide background to the court's characteristically sparse reasoning', so it relied on the submission of the European Commission to 'fill the gap', as it had given 'a much clearer answer' than the ECJ. ${ }^{54}$

This critical attitude of UK judges is perhaps unsurprising, because judges in common law jurisdictions 'cannot be loose with language' and primarily examine the reasoning in a judgment. ${ }^{55} \mathrm{~A}$ UK barrister confirmed this while suggesting that judges have become more critical of the style and reasoning of ECJ judgments, which are not considered intellectually rigorous. ${ }^{56}$ The barrister condemned the 'poverty of reasoning' in past ECJ judgments, but observed that under Lenaerts, some Grand Chamber judgments have shown higher regard for reasoning and greater intellectual rigour. ${ }^{57}$ Such criticisms were voiced less frequently in Ireland and the Netherlands. ${ }^{58}$ Dutch and Irish judges had fewer problems with the brevity of ECJ rulings. One judge noted that it is almost always possible to interpret a brief ECJ judgment further on the basis of earlier rulings. ${ }^{59}$ Other interviewees emphasized that the ECJ need not go into all points in the order if the referring court has already highlighted all sides of the case. They considered it a compliment to the referring court when the ECJ deals with the question in such a (brief) way. ${ }^{60}$

For Dutch judges, it is not the brevity of ECJ judgments that is problematic so much as their abstract and ambiguous nature: they often contain general criteria for the referring court to assess, instead of a clear-cut, yes-or-no answer that practically disposes of the case.$^{61}$ Some Dutch judges felt that the number of such deference judgments has increased in recent years. ${ }^{62} \mathrm{~A}$ good example is $A, B, C$, about a court's assessment of the credibility of the declared homosexual orientation of an asylum seeker. According to some judges, the ECJ

54 Barritt 2015; 370. ClientEarth, $R$ (on the application of) $v$ The Secretary of State for the Environment, Food and Rural Affairs [2015] UKSC 28 (Lord Carnwath), paras 6 and 10.

55 Interview 133. Cf Interview 155; Arnull 2010, 81.

56 UK courts seem to consider ECtHR judgments of better quality because of the option of dissenting judgments, Interview 211. Cf Nicola 2017, 1509.

57 Interview 211.

58 One Dutch Supreme Court judge (41) held that 'in terms of workmanship, sharp editing is less highly regarded' at the ECJ than the Supreme Court.

59 Interview 34.

60 Interviews 33 and 82.

${ }_{61}$ Judges also criticized Case C-579/13 P and $S$ EU:C:2015:369; Interviews 66, 72, 81 and 89 .

62 Interviews 43, 48, 66, 81 and 89. 
mentioned only what the courts could not do - that is, submit the asylum seeker to questioning based on stereotypical notions or sexual practices, or to some kind of 'test' aimed at establishing his or her homosexuality. The ECJ provided no indications as to what is allowed in order to establish the credibility of the assertion. ${ }^{63}$ One judge even asked whether the reference was ultimately useful, because of the time lost as a result and the fact that the ECJ left it completely up to the national court to resolve the case on the basis of considerations that the Council of State had already identified and discussed before the reference. Dutch Supreme Court judges voiced similar concerns over the questions in Commerz, on whether the arbitrary and unlawful actions of the sole director of the Port of Rotterdam Authority could be attributed to the municipality. In its reference, the Supreme Court presented two options: no attribution, because the municipality was not really involved in the specific case; or attribution, based on the municipality's general involvement in the port authority. The judges noted that the ECJ failed to choose between the two options identified in the order for reference, and instead left it to the Supreme Court to decide 'in the light of all the relevant evidence'. The judges interviewed noted that they had already done so, and thus the reference left them no wiser on this point. ${ }^{64}$ Another example is Martens, which considered a requirement to qualify for the continued grant of funding for higher education outside the Netherlands that the applicant have resided in the Netherlands in at least three of the six years preceding enrolment. The ECJ stated that this rule was not consistent with EU law, but provided little clarity on the factors that the Central Appeals Tribunal should consider to find a genuine link with the Netherlands. ${ }^{65}$ In Residex, the Dutch Supreme Court asked whether it had the power - or even the obligation - to annul a guarantee given to a lender where this constituted unlawful state aid. ${ }^{66}$ According to one interviewee, the Supreme Court asked a general question and received a very general answer, from which it 'had not progressed any further'. One example of an ambiguous deference judgment resulting from a UK reference is the environmental case of Edwards, which concerned the requirement that the costs of litigation not be 'prohibitively expensive' within the meaning of Article 9(4) of the Aarhus Convention. ${ }^{67}$ Lord Carnwath noted rather grumpily that the ECJ did not provide 'a simple or straightforward

${ }^{63}$ Joined Cases C-148/13 to C-150/13 A, B, C EU:C:2014:2406; van Gestel and de Poorter 2019, 87.

${ }^{64}$ Case C-242/13 Commerz EU:C:2014:2224; Interview 27.

65 Case C-359/13 Martens EU:C:2015:118.

66 Case C-275/10 Residex EU:C:2011:814.

67 Another example is Watson, which was 'lacking in clarity' and led to disputes between the parties. Joined Cases C-203/15 and C-698/15 Tele2 Sverige and Watson EU:C:2016:970; SSHD v Watson \& Ors [2018] EWCA Civ 70. 
answer' as to whether there is an objectively determined lower limit and, if so, how it should be assessed, even though this was one of the main issues raised by the House of Lords in its reference. ${ }^{68}$ One might question, however, whether it is possible - or desirable - for the ECJ to do more than interpret EU law at a general and abstract level, especially when there are significant differences between EU Member States in relation to such a procedural issue. ${ }^{69}$

Judges thus generally prefer outcome judgments that give a very specific answer, leaving the national court no margin for manoeuvre. ${ }^{70}$ The advantage of such judgments is that they limit the discussion between the parties after the ECJ judgment has been delivered, and may preclude the need for another hearing and a follow-up judgment from the referring court. ${ }^{71}$ Dutch Supreme Court judges, for example, were quite satisfied with GS Media, in which the ECJ applied its interpretation of 'communication to the public' and concluded that it appeared, 'subject to the checks to be made by the referring court', that hyperlinks to websites with leaked nude photographs constituted such a communication. ${ }^{72}$ Dutch tax judges were also content with concrete judgments that were criticized in the literature for being too interventionist. They considered that such judgments are unavoidable where the interpretation could lead to only one outcome. ${ }^{73}$ Hence, most judges disagreed with the observation that national courts are wary of overly detailed or interventionist judgments that reduce their own latitude and room for manoeuvre. ${ }^{74}$ The only judgment that was criticized for this reason was Josemans, about the Maastricht 'weed pass', which prohibits the admission of Dutch non-residents to coffee shops. The ECJ went quite far in its judgment and applied its interpretation of the freedom to provide services (currently Article 56 TFEU) to the local rule. After conducting a proportionality assessment, the ECJ concluded that the rule could be justified by the objective of combating drug tourism and the accompanying public nuisance, and found that the rules did not go beyond what was necessary to achieve this objective. One interviewee was critical of this decision, noting that

\footnotetext{
68 Edwards \& Anor, $R$ (on the application of) $v$ Environment Agency \& Ors (No 2) [2013] UKSC 78, para 31. Cf Kokott and Sobotta 2019, 121.

${ }_{69}$ Heyvaert et al 2014.

70 Mance 2013a, para 23. Cf Nicola 2017, 1530; van Gestel and de Poorter 2019, 72.

Interviews 69 and 77.

Case C-160/15 GS Media EU:C:2016:644, para 54; Interviews 27, 45 and 87.

73 Interviews 15 and 34. For example, Case C-59/16 The Shirtmakers EU:C:2017: 362; Case C-520/14 Gemeente Borsele EU:C:2016:334.

74 Davies 2006, 232; Komárek 2007, 467; Tridimas 2011, 754; de la Mare and Donnelly 2011, 391 .
} 
the ECJ had restricted the referring court's room for manoeuvre and simply left it to 'tick the box'. 75

That said, however, it is unfair to blame the ECJ alone for ambiguous answers. It is the responsibility of the referring court to draft the questions as concretely as possible. It is the referring court that determines the kinds of questions that will be answered. General or unclear questions often lead to general or vague answers - which, in the words of one Dutch judge, can be a 'subscription to frustration' ${ }^{76}$ For example, the judges suggested that the Supreme Court should 'put its hand on its heart' and assume responsibility for the outcome in the Residex case, as it should have provided more detail on the Dutch private law context and its subtleties in its order for reference. ${ }^{77}$

\subsection{Reformulation of Questions}

It is a common practice of the ECJ to reformulate the questions of the referring court. Most of these reformulations are not substantive; the ECJ simply rephrases the questions in the language of EU law, which can be understood in all EU Member States. ${ }^{78}$ Judges appreciate that the ECJ will frame the questions as European issues and will 'dislocate' them from the domestic context - especially where the questions have been badly worded. ${ }^{79}$ Judges nonetheless considered reformulations to be problematic where the original questions remain unanswered and the ECJ takes a different direction - especially if the referring court had initially formulated the questions 'with precision' ${ }^{80}$ The judges interviewed also found it annoying when the ECJ neglects the suggestions of the referring court, but fails to provide clear reasons for doing so. ${ }^{81}$ One Irish judge noted the 'problem of getting the ECJ to answer the question you want them to answer and not to avoid the hard question'. ${ }^{82}$ Van Gestel and de Poorter confirm that these sentiments are shared by judges of the supreme

75 Case C-137/09 Josemans EU:C:2010:774, para 83.

76 Interviews 32 and 83.

77 Cf Sieburgh, attributed to the poor explanation of the modalities in Dutch civil law, Sieburgh 2011, 239; Loth 2014, 22.

78 Šadl and Wallerman 2019.

79 Interview 113. Cf van Gestel and de Poorter 2019, 81.

80 Interviews 12, 24, 65, 66, 89, 108, 113, 152, 161, 162, 166 and 174; Langer 2015, 12; Garcia Antón 2015; van Gestel and de Poorter 2019, 8 and 81; Société Des Produits Nestlé SA v Cadbury UK Ltd [2016] EWHC 50 (Ch) paras 11 and 45.

81 One example is Unal, on the withdrawal of the residence permit of a Turkish worker with retroactive effect. The Council of State explicitly held that there was no fraud, but that did not prevent the ECJ from dealing with this matter, Case C-187/10 Unal EU:C:2011:623, paras 45-48; Wissels 2015, 551.

82 Interview 174. 
administrative courts in other Member States, including France, Germany, the Czech Republic and Poland. ${ }^{83}$

Substantive and allegedly incorrect reformulations arose quite a few times in relation to Dutch references in the five-year period under review; but this happened less frequently in relation to Irish and UK references. ${ }^{84}$ In Danqua, the Irish Court of Appeal referred a question on the 15-day time limit for applications for subsidiary (asylum) protection in relation to the principle of equivalence. ${ }^{85}$ The ECJ considered this question 'irrelevant' and reformulated it ('must be understood') to a question of whether the principle of effectiveness precluded the Irish procedural rule (answer: yes). ${ }^{86}$ The referring judge, Hogan, was very critical of the ECJ answering questions that had not been raised in the order for reference, especially because the principle of equivalence was not a point of discussion in the domestic proceedings. ${ }^{87}$ Similarly, the well-known and slightly older UK case of Aimia Coalition ${ }^{88}$ had, in the words of one UK Supreme Court judge, a 'disastrous' and 'shambolic' outcome. ${ }^{89}$ Instead of answering the questions of the House of Lords on the interpretation of the VAT Directive, the ECJ reformulated the questions and examined the VAT treatment of the payments in the particular case. In doing so, the ECJ failed to understand the actual point of contention and all the relevant facts..$^{90}$ The ECJ also combined this case with another reference of the House of Lords, which made the answer 'difficult to unravel' in the absence of an AG Opinion. ${ }^{91}$ Another UK example is Nestlé, referred by High Court judge Arnold, who has extensive experience of the preliminary reference procedure. He entertained doubts as to whether the ECJ had understood the (reformulated) question, given the 'translation issues', and pointed to the resulting lack of clarity of its answers. ${ }^{92}$ Another UK case in which the ECJ did not reformulate the

\footnotetext{
83 Van Gestel and de Poorter 2019, 127.

$84 \quad$ Interviews 22, 108, 161, 166 and 174.

85 Evelyn Danqua v Minister for Justice [2015] IECA 118 (Hogan J); Interview 166.

86 Case C-429/15 Danqua EU:C:2016:789, paras 35-36 and 38.

87 Evelyn Danqua v Minister for Justice [2017] IECA 20 (Hogan J), paras 1, 3, 15 and 19.

${ }_{88}$ Another case in which the ECJ 'sought to rephrase the question but in doing so asked a different question which it then went on to decide' is Case C-115/15 NA EU:C: 2016:487; Pokuah v SSHD [2017] UKAITUR EA112612016, para 27.

89 Interview 208.

90 Reed 2014, 12.

91 Para 49; HMRC v Aimia Coalition Loyalty UK Ltd [2013] UKSC 15 (Lord Hope), para 88 .

92 Société Des Produits Nestlé SA v Cadbury UK Ltd [2016] EWHC 50 (Ch), paras 9-11, 22 and 45.
} 
question, but added an element that the UK Supreme Court had intentionally left out, is Alemo-Herron. This ECJ judgment has been criticized by scholars as 'downright odd' for placing too much emphasis on the freedom to conduct business over the rights of employees and collective bargaining. The ECJ, on its own initiative, asserted the right to conduct business as laid down in Article 16 of the Charter, even though the Supreme Court had held that the right to freedom of association was not an issue and domestic law was consistent with the common law principles of freedom of contract. ${ }^{93}$

One Dutch example is Franzen, in which the Dutch Central Appeals Tribunal asked whether a social security allowance 'must' be provided on the basis of EU law; the ECJ determined only that this was at the discretion of the authorities ('may'). Dutch judges complained that the reference was a useless exercise, because they already knew that answer. ${ }^{94}$ The Supreme Court thus found it necessary to refer the question a second time on appeal. ${ }^{95}$ Another slightly different case is T-Mobile: one interviewee was offended that the ECJ had assigned a certain point of view to the Trade and Industry Appeals Tribunal, which it did not in fact have. The Tribunal asked an open question, proposing different options for possible answers; but the ECJ seemed to suggest that the Tribunal wanted to 'push down the throat' a particular interpretation. ${ }^{96}$

Once again, however, it is frequently not only the ECJ that must shoulder the blame in such scenarios. One judge interviewed expressed sympathy for the ECJ, because it can only deal with what it is presented with. ${ }^{97}$ In Danqua, the Court of Appeal insufficiently set out the national legal framework in its order of reference, as AG Bot also noted. ${ }^{98}$ In Aimia Coalition, the ECJ went wrong at an early stage due to the minimal and deficient reference made by the House of Lords, which failed to identify the central issues and relevant facts clearly, as Lord Reed highlighted. ${ }^{99}$

\footnotetext{
93 Case C-426/11 Alemo-Herron EU:C:2013:521, para 31; Parkwood Leisure Ltd v Alemo-Herron \& Ors [2011] UKSC 26, para 9; Gill-Pedro 2017; Weatherill 2014.

94 Case C-382/13 Franzen EU:C:2015:261, paras 56 and 67; Franzen NL:CRVB: 2013:783, paras 4.18 and 10.8.

95 Joined Cases C-95/18 and C-96/18 Van den Berg, Giesen and Franzen EU:C: 2019:767.

96 Case C-8/08 T-Mobile EU:C:2009:343.

97 Interview 208.

98 Case C-429/15 Danqua EU:C:2016:485, paras 21 and 26.

99 Reed 2014, 12; Joined Cases C-53/09 and C-55/09 Loyalty Management UK and Baxi Group EU:C:2010:590, paras 31-32.
} 


\section{$2.4 \quad$ Lack of Consistency}

Dutch and UK Supreme Court judges are especially critical of the lack of consistency in the ECJ case law, and even of mutual inconsistencies within a judgment as a result of the required unanimity among the judges and the absence of dissenting and concurring opinions. ${ }^{100}$ Lord Carnwath observed that 'a search for logical coherence in the Luxembourg case-law is probably doomed to failure'. ${ }^{101}$ One Dutch judge held that the ECJ pays insufficient attention to the position of a judgment within the 'edifice' of its case law, which stands in contrast to the strong focus on judicial law making of the Dutch Supreme Court. ${ }^{102}$ One Irish judge argued: 'There is a pretence that the law is a continuous march. Major changes in the jurisprudence are camouflaged and not even admitted when there are contradictory judgments. ${ }^{103}$ Lady Justice Arden likewise mentioned that the ECJ fails to explain why it has deviated from its own jurisprudence. ${ }^{104}$

Dutch and UK judges were unanimous in their criticisms of judgments in patent and trademark cases, and especially the ECJ's casuistic and 'not entirely consistent' case law on 'communication to the public' and 'the essential function of a trade mark'. ${ }^{105}$ One judge interviewed suggested: 'There's neither rhyme nor reason to it.' ${ }^{106}$ Interviewees attributed these inconsistencies to the (increasingly) fact-oriented approach of the ECJ, resulting in a casuistic case law that leads to more questions in subsequent cases in which the facts are (slightly) different. ${ }^{107}$ Former High Court judge Arnold, who has made several IP references, observed that - unhelpfully - the ECJ does not explicitly make clear when earlier judgments are no longer considered authoritative or are restricted to their own facts. ${ }^{108}$ The inconsistent jurisprudence in the field of IP law was also attributed to a lack of specialist expertise at the ECJ. ${ }^{109}$ Arnold, for example, stated extra-judicially: 'Given its lack of experience in the highly specialised field of patent law, it is not surprising that the ECJ has had difficulty

100 Interviews 27, 30, 41, 45, 87 and 231. Cf Jacobs et al 2019, 1215.

101 Oss Group Ltd, $R$ (on the application of) $v$ Environment Agency \& Ors [2007]

EWCA Civ 611, para 55.

102 Interviews 33, 78 and 87.

103 Interview 139. Cf Interviews 136 and 144.

104 Arden 2010, 8 and 19.

105 Specsavers International Healthcare Ltd v Asda Stores Ltd [2012] EWCA Civ 24

(Kitchin LJ), para 179; Interviews 27, 87 and 231.

106 Interviews 45 and 87.

107 Cf Bobek 2020, 87-88.

108 Abraxis Bioscience Llc v The Comptroller-General of Patents [2017] EWHC 14

(Pat), para 44. Cf Arnold 2020, 1105-06.

109 Cf Favale et al 2016; Oliver and Stothers 2017, 564-65. 
in understanding the complex background to many of these issues and in devising workable solutions. ${ }^{\prime 10}$ One Dutch judge observed that the ECJ is full of judges with a competition law background. ${ }^{111}$ Another stated that there is 'an occasional sigh' that there are so many (economic) administrative lawyers at the ECJ, who are not sufficiently familiar with private law. ${ }^{112}$ Lord Mance also lamented the lack of expertise in the area of private law more generally. ${ }^{113}$ The UK courts have been critical of inconsistences in the ECJ case law both on the principle of proportionality and on the SPC Regulation. ${ }^{114}$

There have also been complaints about inconstancies in the case law on direct taxes for natural persons. One former Dutch Supreme Court tax judge stated that he sometimes had 'to grit my teeth' over occasional ECJ judgments that failed to pay attention to the wider case law. ${ }^{115}$ For example, some interviewees suggested that it is difficult to square Schumacker with subsequent ECJ judgments. ${ }^{116}$ The Schumacker doctrine implies that Member States cannot withhold tax advantages linked to personal and family circumstances, such as the deduction of maintenance or medical expenses, from non-residents working in the relevant Member State if they are also granted to residents. ${ }^{117}$ The ECJ did not apply Schumacker on a time-proportional basis in Kieback, despite the clear preference of the Dutch Supreme Court, the Dutch lower courts and AG Sharpston. ${ }^{118}$ Shortly thereafter, the ECJ nonetheless decided that tax deductions can be made in proportion to income if the person has worked in multiple EU Member States. ${ }^{119}$ Several tax law judges, scholars and legal practitioners criticized the inconsistencies between these two judgments. AG Wattel, for example, lamented that the case law is difficult to comprehend. ${ }^{120}$ Again, the judges interviewed attributed the inconsistencies to a lack of specialist knowledge of tax and VAT law at the ECJ. ${ }^{121}$ As a result, EU law

110 Arnold 2020, 1105.

111 Interview 87.

112 Interview 27.

113 Mance 2011, para 32.

114 Lumsdon \& Ors, R (on the application of) v Legal Services Board [2015] UKSC

41; Glaxosmithkline Biologicals SA v Comptroller-General of Patents, Designs and Trade Marks [2013] EWHC 619 (Pat) (Birss J), para 86.

115 Bergman and Van Zadelhoff 2017.

116 Interviews 30 and 78.

117 Case C-279/93 Schumacker EU:C:1995:31.

118 Case C-9/14 Kieback EU:C:2015:406; Kieback NL:HR:2013:167, para 3.5.6.

119 Case C-283/15 X. EU:C:2017:102

120 Interview 30; NL:PHR:2016:118.

121 Interviews 37 and 78. 
lawyers may find an ECJ ruling logical, while tax lawyers wonder, 'How could they do that?' 122

\section{INSUFFICIENT APPRECIATION OF THE NATIONAL CONTEXT}

Also problematic are judgments in which the ECJ applies the national legal framework (section 3.1) or the facts (section 3.2) incorrectly, or does not take the concerns of the referring court seriously (section 3.3). ${ }^{123}$ There are fewer judgments in this category than in the previously discussed category of silent or unclear judgments. As with many of these judgments, national courts are responsible for clearly outlining the domestic legal and factual framework in the order for reference, which means that the referring court must also shoulder some of the blame in the cases discussed below.

\subsection{Incorrect Reading of National Law}

The ECJ traditionally abstains from interpreting national legal frameworks. Nonetheless, however, in a small number of cases the ECJ has misconstrued the applicable provisions of national law. ${ }^{124}$ This occurred in the Franzen social security case: the ECJ did not answer the third question because it wrongly assumed that the Central Appeals Tribunal was not obliged, but merely allowed, to apply the hardship clause in order to remedy unacceptable unfairness. ${ }^{125}$ The ECJ also seemed to assume that this was left to the discretion of the referring court instead of the administrative authorities. Dutch judges found this ECJ judgment 'annoying' and pointed to the lack of communication on this point; in particular, they suggested that the ECJ gave the impression that it did not understand the importance of the question(s) at issue. The judges also wondered whether the ECJ understood the functioning of the Dutch social security system at all - not least because this was the second time that it had made a mistake in relation to the hardship clause. ${ }^{126}$ One interviewee did not want to play the blame game, but noted that the answers of the ECJ caused problems and did not allow the Supreme Court to resolve the case; the Tax

122 Interview 37.

123 Cf Jacobs et al 2019, 1217.

124 Cf Eliantonio and Favilli 2020.

125 Case C-382/13 Franzen EU:C:2015:261, paras 56 and 67; Franzen NL:CRVB: 2013:783, paras 4.18 and 10.8 .

126 The hardship clause was only introduced in 2002, but the ECJ assumed that the clause applied to Hendrix even though the facts of the case pre-dated the entry into force, C-287/05 Hendrix EU:C:2007:494. 
Chamber consequently decided to refer follow-up questions. ${ }^{127}$ Once again, however, one might ask whether the ECJ should exclusively be blamed here, as the Central Appeals Tribunal had provided minimal information on Dutch law. One Dutch judge recognized this and indicated that the Dutch courts should pay extra attention to the formulation of questions and the drafting of the order for reference in future cases. The option of re-referral was also recently discussed in two joined cases on corporation tax and a single tax entity after an ECJ judgment based on a misunderstanding of Dutch tax law. ${ }^{128} \mathrm{AG}$ Wattel noted that the Supreme Court could also be blamed for these 'blunders', since it had not asked the right questions. He nonetheless advised against re-referral, because the case could be resolved based on ECJ case law. ${ }^{129}$

Only one Irish case - albeit a prominent one - was found in this category: the 'long-running drama' of $M M$, which played out over 11 years. ${ }^{130}$ Like Danqua, this case dealt with the Irish subsidiary asylum protection scheme. While most EU Member States have a single procedure for asylum and subsidiary protection claims, Ireland has a system whereby applicants whose application for refugee status is refused can subsequently apply for subsidiary protection. $M M$ was referred twice: first by the High Court in 2011 and later by the Supreme Court in 2014. High Court judge Hogan asked in 2011 whether the administrative authorities are obliged to supply an applicant with a draft decision on the application for subsidiary protection before a final decision is made, given that the first refugee application was rejected. The ECJ determined that there is no such obligation. ${ }^{131}$ To Hogan's dismay, the ECJ 'went beyond the scope of the referred question' and examined 'the more general question of fair procedures' and the right to a hearing. ${ }^{132}$ The ECJ concluded that the fact that the applicant had already been duly heard in the (first) refugee procedure did not mean that the right to be heard could be dispensed with in the second subsidiary protection procedure. Hogan lamented that this point was never argued before the High Court. He also pointed to another 'complicating issue': the ECJ had incorrectly 'ascribed certain views' to the referring court, ${ }^{133}$ and seemed to assume that procedural safeguards were lacking and that there was

\footnotetext{
127 Joined Cases C-95/18 and C-96/18 Van den Berg, Giesen and Franzen EU:C: 2019:767.

128 Joined cases C-398/16 and C-399/16 X EU:C:2018:110, paras 14-17.

129 NL:PHR:2018:624, paras 1.7, 1.9 and 1.13; NL:PHR:2018:687.

130 Interviews 113, 128, 144, 152, 159, 171 and 181; MMv Minister for Justice [2018] IESC 10 (O’Donnell J), para 31.

131 Case C-277/11 M.M. EU:C:2012:744.

132 MR \& Anor $v$ An t-Ard Claraitheoir \& Ors [2013] IEHC 91 (Hogan J), paras 6 and 22. Cf MMv Minister for Justice [2018] IESC 10 (O'Donnell), para 10.

133 Evelyn Danqua v Minister for Justice [2017] IECA 20 (Hogan J), paras 34-35.
} 
no possibility at all to make submissions. ${ }^{134}$ Several interviewees noted that the ECJ had 'fundamentally misunderstood' the context of the case and offered its views on the subsidiary protection system without having all the details. ${ }^{135}$ One interviewee suggested that the ECJ should not have dived into the national context in this way. ${ }^{136}$ The case reached the Supreme Court in 2014. The court basically asked whether the ECJ had truly understood the Irish procedure and whether Hogan's inference in fact went too far. ${ }^{137}$ It asked whether the right to be heard requires an oral hearing. This time, the ECJ answered clearly and noted that a personal interview is not always required. ${ }^{138}$ The $M M$ saga is a perfect example of 'lost in translation', with the courts talking across each other, as the Irish Supreme Court observed in its follow-up judgment. ${ }^{139}$

Yet again, however, it not only the ECJ that can be blamed here. From a national perspective, it is easy to argue that the ECJ has simply failed to understand the domestic context. ${ }^{140}$ But if the ECJ has failed to understand national law, this is due mainly to the referring court's failure to provide a sufficient explanation. ${ }^{141}$ The 'lost in translation' situation in $M M$ partly resulted from the order for reference: it discussed a bifurcated system, implying a choice between the two procedures (asylum and subsidiary), when in reality this is more of a two-step system. ${ }^{142}$ The order did not provide sufficient information on the procedure and the High Court should have stated what would be obvious to every Irish lawyer - namely, that a hearing implies an oral hearing in common law jurisdictions. ${ }^{143}$ The previous account also revealed that the information provided by the referring Dutch court on Dutch social security law in Franzen was too limited.

\subsection{Incorrect Reading of the Facts}

Judges in all three countries also considered it problematic when the ECJ 'descends' into the national arena and applies its interpretation to the facts of the case. This is especially true when the ECJ bases its decision on the wrong facts or when the facts were not a point of discussion in the domestic proceed-

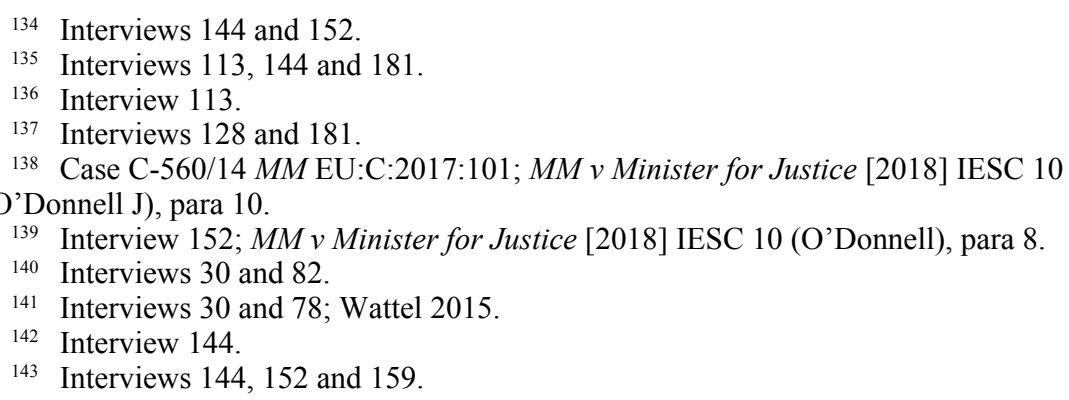


ings. ${ }^{144}$ One classic example is the disapproval expressed in the follow-up judgment of the UK House of Lords in Factortame, which concerned the notion of state liability for sufficiently serious breaches of EU law. The House of Lords emphasized that it is the 'sole jurisdiction' of national courts to identify the facts and determine whether breaches of EU law are sufficiently serious, and expressed its displeasure with the ECJ's 'blunt' characterization of the nature of the breach. Lord Hope was thus not 'inclined to attach much importance to these expressions of opinion' ${ }^{145}$

Factual 'interference' in itself was not viewed as problematic. ${ }^{146}$ In fact, it is sometimes even helpful when the ECJ shines further light on how it views the resolution of the case, as this can 'elucidate the abstract statement of law'. ${ }^{147}$ GS Media was previously cited as an example of this. In that case, the ECJ applied its interpretation of 'communication to the public' and concluded that a hyperlink to a website with leaked nude photographs constituted such a communication. ${ }^{148} \mathrm{~A}$ factually oriented outcome judgment is also inevitable in cases where the interpretation of the ECJ can lead only to one outcome. ${ }^{149}$ It is difficult for a court to deliver a judgment without considering the facts, especially where the referring court has referred a very specific and detailed question, or where the legal area is highly fact sensitive - as is the case, for example, with VAT. ${ }^{150}$

However, some Dutch interviewees noted that the ECJ should avoid such factual determinations where the facts are established and can no longer be the subject of judicial review at the stage of cassation before the Supreme Court. ${ }^{151}$ This issue has been the subject of discussions between the Dutch Supreme Court and the ECJ (Chapter 5, section 4). ${ }^{152}$ One example of a factually oriented ECJ judgment is that in Ladbrokes, on online games of chance. The Dutch Supreme Court had stated explicitly in its order for reference that it had been established in cassation that the betting activities were limited in

144 Mance 2013a, para 15; Interviews 27, 41, 48, 59 and 87.

$145 R v$ The Secretary of State for Transport, ex parte Factortame Ltd (No 5) [2000]

1 AC 524, paras 542 and 550.

${ }_{146} R$ (on the application of Newby Foods Ltd) $v$ Food Standards Agency [2019]

UKSC 18, para 69.

${ }_{147}$ Newby Foods Ltd, $R$ (on the application of) v Food Standards Agency [2017]

EWCA Civ 400, para 49; Interview 33, 82.

${ }_{148}$ Case C-160/15 GS Media EU:C:2016:644, para 54; Interviews 27, 45 and 87.

149 Interview 15.

150 Interviews 30, 34 and 59; Reed 2014, 12; Case C-520/14 Gemeente Borsele EU: C:2016:334.

151 Interviews 15, 27, 30, 41, 48, 59, 82 and 87.

152 Interview 15. 
a consistent and systematic manner. ${ }^{153}$ The ECJ, however, examined whether this was indeed the case and ultimately concluded that it was not, contrary to the Supreme Court's finding. ${ }^{154}$ According to one interviewee, this resulted in 'an enormous struggle' for the Supreme Court. ${ }^{155}$

The Tax Chamber of the Dutch Supreme Court was confronted with a similar problem in a customs case about the tariff classification of standalone music devices (Sonos). The ECJ had itself consulted the manufacturer's website in order to verify how the product was presented to consumers. ${ }^{156}$ Several interviewees noted that the ECJ should not have done this, because the facts had already been established for the court of cassation and were not subject to review. However, this determination did not prove too problematic for the Supreme Court in delivering its final judgment. As we shall see in Chapter 7 , section 3, the Dutch and UK courts have found a way around the difficulties caused by factual determinations of the ECJ by concluding that they are not bound by ECJ rulings on the facts.

Of course, national courts can prevent such factual determinations by the ECJ to a certain extent by doing their utmost to set out all the relevant factual circumstances in the order for reference. In addition, the referring court should not be too quick to disregard parts of an ECJ ruling on the grounds of an allegedly wrongful appraisal of the facts. One such example is Newby, which concerned EU food hygiene rules for meat products. The UK High Court was critical of the ECJ's mistaken findings of fact: according to the High Court, the ECJ had wrongly relied on the intervention of the French government and held that certain chicken and pork products were obtained from bone scrapings. By contrast, the High Court had previously found that the products in fact comprised fresh meat. Both the High Court and the Court of Appeal considered that the referring court was not bound by the ECJ's determination of facts in that particular case, relying on the Aimia precedent of the UK Supreme Court. ${ }^{157}$ The UK Supreme Court eventually sided with the ECJ and noted that the ECJ had accurately summarized the position of the referring court in its reference judgment and was entitled to pronounce on the application of its interpretation to the case. ${ }^{158}$

\footnotetext{
153 Ladbrokes NL:HR:2008:BC8970, para 4.16.

154 Case C-258/08 Ladbrokes EU:C:2010:308, paras 21-38.

155 Ladbrokes NL:HR:2012:BT6689, para 2.9.4.

156 Case C-84/15 Sonos EU:C:2016:184; see the subtle reference to the ECJ's intervention in Sonos NL:HR:2016:1347, para 2.3.

157 Newby Foods Ltd, R (on the application of) v Food Standards Agency [2016] EWHC 408 (Admin), paras 39, 84 and 89; [2017] EWCA Civ 400, para 54.

158 Newby Foods Ltd, $R$ (on the application of) v Food Standards Agency [2019] UKSC 18, para 70.
} 


\subsection{Concerns Not Taken Seriously}

Underlying many of the cases discussed in this chapter was a feeling among judges that the ECJ had not taken their concerns seriously and had disregarded their carefully prepared questions. ${ }^{159}$ This coincides with Weiler's argument that the ECJ should clearly show that national sensitivities have been considered. ${ }^{160}$

Some mentioned Trijber and Harmsen as an example, because the ECJ avoided the Council of State's question about the application of the Services Directive in purely internal situations. ${ }^{161}$ The ECJ did not adequately recognize that the referred issue was an important problem for the Netherlands. It did not reflect on the possible negative consequence that anyone could challenge national measures before the court if mere hypothetical cross-border elements were sufficient grounds to do so. It seems that the ECJ listened the second time round and took the reference in Visser Vastgoed more seriously, because of the Grand Chamber formation assigned to that case.

Something similar had occurred a few years earlier, in ESF/Somvao. According to several judges, the ECJ came up with a rather unconvincing answer in ESF concerning subsidies from the European Social Fund. Dutch legal practitioners and academics were dissatisfied with this ruling because the ECJ required full recovery of the granted subsidies. This was at odds with the principle of the protection of legitimate expectations. ${ }^{162}$ The Council of State felt that it had not been taken seriously, and that the ECJ had insufficiently understood that this was an important issue in the Netherlands. The Council of State was thus required to ask a follow-up question in Somvao, this time about the recovery of wrongfully granted subsidies from the European Refugee Fund.

Cases in which the ECJ has ignored the explicit considerations of the referring court and opted for a different approach without substantive reasoning are even more problematic. ${ }^{163}$ One famous example is Melloni, which was referred by the Spanish Constitutional Court. The ECJ disregarded the provisional answers proposed by the referring court without elaborating on the arguments presented. It adhered closely to the primacy and effectiveness of EU law, and upheld the validity of the Framework Decision on the EAW. This left little room for the Constitutional Court to achieve a reconciliatory solution

159 Interviews 10, 12, 89 and 91.

160 Weiler 2001, 225.

161 Joined Cases C-340/14 and C-341/14 Trijber and Harmsen EU:C:2015:641.

162 Case C-383/06 ESF EU:C:2008:165; Case C-599/13 Somvao EU:C:2014:2462; Wissels 2015, 551.

163 Case C-187/10 Unal EU:C:2011:623; Wissels 2015, 551. 
by interpreting the decision and the Charter in conformity with the higher level of protection of the right to a fair trial of persons convicted in absentia under the Spanish Constitution. ${ }^{164}$ Another such case is Diageo Brands, referred by the Civil Chamber of the Dutch Supreme Court. Judges were frustrated by the 'startling' handling of this reference by the ECJ, which led to the 'breakdown of two systems'. The Supreme Court asked whether it was required to recognize the judgment of a Bulgarian court which was based on a Bulgarian Supreme Court ruling that had 'manifestly misapplied EU law', including in the view of the European Commission. ${ }^{165}$ In its order for reference, the Supreme Court implicitly presented its preference for non-recognition by mentioning that there were good reasons to refuse execution of such an erroneous judgment. The ECJ disagreed with the Supreme Court, and instead favoured the principles of mutual recognition and mutual trust. The judges interviewed criticized the ECJ's 'political manipulation' by the Commission, which had subsequently withdrawn its earlier determination of a breach and concluded that the Bulgarian court decisions were consistent with EU law; they spoke of a 'political deal' with Bulgaria. In agreeing with the Commission and AG Szpunar, the ECJ did not address the underlying concerns of the Supreme Court and its 'conviction' that there had been a serious breach. ${ }^{166}$ This incident also confirms that other players can sometimes have more influence than the referring court and frustrate the process, as discussed in Chapter 5, section 3.

\section{CONCLUSION}

This chapter has discussed two specific perceived problems with ECJ judgments: the ECJ's inability to answer the questions satisfactorily, if at all; and its failure to appreciate the facts of the case, the national legal framework or the underlying concerns of the referring court. It should be stressed at the outset that these are exceptions that prove the rule of general satisfaction with ECJ judgments. The question is how much importance should be attached to them. One UK judge noted that individual cases 'stick in the minds of judges' ${ }^{167}$ In the interviews, judges tended to focus on these outliers, suggesting that one problematic case has a greater impact than several good rulings. This leads to the question of whether the criticisms of national court judges deserve wider

164 Case C-399/11 Melloni EU:C:2013:107; Pérez 2014; van Gestel and de Poorter $2019,51$.

165 The Supreme Court based this conclusion on a letter of the Commission in which the Commission held that lower courts cannot follow the Bulgarian Supreme Court, Diago Brands NL:HR:2013:2062, paras 5.2.2, 5.3.2; Interviews 27 and 87.

166 Case C-681/13 Diageo Brands EU:C:2015:471, paras 54-55; Loth 2017, 65.

167 Interview 264. 
dissemination, especially at a time when the European legal order and the ECJ are under fire. The aim of this overview is not to condemn the ECJ, but rather to provide constructive criticism and highlight deficiencies that could be addressed in order to improve the functioning of both the preliminary reference procedure and the ECJ (see Chapter 8, section 2). ${ }^{168}$

The cases discussed in this chapter also prompt the question of why the Irish courts and - to a lesser extent - the Dutch Supreme Court are more positive than the UK courts and the Dutch highest administrative courts about the answers of the ECJ. The positive views of the Irish courts can perhaps be attributed to their reference of mostly closed questions. These questions more frequently result in outcome judgments in which the ECJ de facto decides the case on the merits, because it gives very specific answers that leave the national court with no margin for manoeuvre. ${ }^{169}$ Hence, very few ECJ rulings referred by Irish courts generated an argument during the hearing. ${ }^{170}$ By contrast, the more positive outlook of the Dutch Supreme Court seems related to its more apolitical nature. The Dutch highest administrative court judges generally thought more in political terms, not least because of the types of cases in which they are involved. They had more ideas about the outcome of a case and the desired interpretation than Supreme Court judges. Because of these ideas and expectations, they were more dissatisfied when the ECJ took a different direction. ${ }^{171}$

Having discussed the satisfaction of the national courts with the answers of the ECJ, we can now consider what the referring courts do with the ECJ ruling in their follow-up judgments. Does dissatisfaction result in non-compliance?

$168 \mathrm{Cf}$ 'Constructive criticism is part of a dialogue which is to be encouraged and which can lead to better and more harmonious understanding', Mance 2013a, para 65.

169 Tridimas 2011, 737.

170 Interviews 148, 152, 153, 155 and 181.

171 Interview 30. 